\title{
Fairness Opinions: How Fair Are They and What Can be Done About It?
}

\section{Citation}

Lucian A. Bebchuk \& Marcel Kahan, Fairness Opinions: How Fair Are They and What Can be Done About It?, 1989 Duke L.J. 27 (1989).

\section{Published Version}

http://scholarship.law.duke.edu/dlj/vol38/iss1/2/

\section{Permanent link}

http://nrs.harvard.edu/urn-3:HUL.InstRepos:12967858

\section{Terms of Use}

This article was downloaded from Harvard University's DASH repository, and is made available under the terms and conditions applicable to Other Posted Material, as set forth at http:// nrs.harvard.edu/urn-3:HUL.InstRepos:dash.current.terms-of-use\#LAA

\section{Share Your Story}

The Harvard community has made this article openly available.

Please share how this access benefits you. Submit a story.

\section{Accessibility}




\title{
FAIRNESS OPINIONS: HOW FAIR ARE THEY AND WHAT CAN BE DONE ABOUT IT?
}

\author{
LUCIAN ARYe BEBCHUK $\dagger$ \\ AND MARCEL KAHAN*
}

\section{INTRODUCTION}

Fairness opinions have become a regular feature of every major corporate control transaction. Whether in negotiated mergers, ${ }^{1}$ freeze-out inergers, ${ }^{2}$ hostile tender offers, ${ }^{3}$ friendly tender offers, ${ }^{4}$ self-tenders, ${ }^{5}$ leveraged buyouts, ${ }^{6}$ negotiated share repurchases, ${ }^{7}$ or negotiated sales of treasury stock, ${ }^{8}$ directors seek the blessing of investment banks before approving transactions or adopting defensive measures. These banks give their blessings in the form of fairness opinions, which usually consist of short letters that state an opinion about whether a proposed transaction is "fair" or "adequate." In addition, the banks often give presenta-

† Professor of Law, Harvard Law School; Faculty Research Fellow, National Bureau of Economic Research.

- Visiting John M. Olin Scholar, fall 1988, Harvard Law School; Associate, Kramer, Levin, Nessen, Kamin \& Frankel. For financial support, both authors are grateful to the Harvard Law School Program in Law and Economics, which is funded by the John M. Otin Foundation. Lucian Bebchuk's work was also supported by the National Science Foundation. The authors thank Irene Khaitman for her helpful research assistance and Andrew Avends for the helpful materials contained in his third-year paper.

1. See, eg., Denison Mines Ltd. v. Fibreboard Corp., 388 F. Supp. 812, 821-22 (D. Del. 1974). See generally Chazen, Faimess from a Financial Point of View in Acquisitions of Public Companies: Is "Third Party Sale Value" the Appropriate Standard?, 36 Bus. LAw. 1439, 1442-43 (1981) (fairness opinions commonplace in merger transactions).

2. See, eg., Anderson v. Boothe, 103 F.R.D. 430, 433 (D. Minn. 1984); Gerstle v. GambleSkogmo, Inc, 298 F. Supp. 66, 82 (ED.N.Y. 1969), modified, 478 F.2d 1281 (2d Cir. 1973); Weinberger v. UOP, Inc., 457 A.2d 701, 707-08 (Del. 1983).

3. See, eg., Dynamies Corp. of Am. v. CTS Corp., 794 F.2d 250, 257 (7th Cir. 1986) (poison pill proposal), re7'd, 481 U.S. 69 (1987); Hanson Trust PLC v. ML SCM Acquisition, Inc., 781 F.2d 264, 271 (2d Cir. 1986) (lock-up option); Unocal Corp. v. Mesa Petroleum Co., 493 A.2d 946, 950 (Del. 1985) (rejected tender offer); MacAndrews \& Forbes Holdings v. Revlon, Inc., 501 A.2d 1239, 1243 (Del. Ch. 1985) (purchase rights issue), aff'd, 506 A.2d 173 (Del. 1986).

4. See, e.g., Danziger v. Kennecott Copper Corp., N.Y.L.J., Dec. 7, 1977, at 7, col. 1.

5. See, eg., Kahn v. United States Sugar Corp., No. 7313, slip op. at 3-5 (Del. Ch. Dec. 10, 1985) (Westlaw, 1985 WL 4449).

6. See, eg., Herskowitz v. Nutri/System, Inc., 857 F.2d 179, 190 (3d Cir. 1988), cert. denied, 109 S. Ct. 1315 (1989); Bebe v. Pacific Realty Trust, 578 F. Supp. 1128, 1135 (D. Or. 1984).

7. See, eg., Kaplan v. Goldsamt, 380 A.2d 556, 561 (Del. Ch. 1977).

8. See, eg., Treadway Cos. v. Care Corp., 638 F.2d 357, 365 (2d Cir. 1980).

9. See, eg., Crouse-Hinds Co. \& Belden Corp., Joint Proxy Statement exhs. C-E (Oct. 14, 1980) (merger is "fair and cquitable"; merger is "fair from a financial point of view"; tender offer is 
tions to boards of directors in which the banks justify and explain their opinions. ${ }^{10}$

One reason why corporate directors obtain fairness opinions is to help persuade shareholders to approve transactions. ${ }^{11}$ More iniportantly, however, directors obtain fairness opinions in order to satisfy their fiduciary obhigations. ${ }^{12}$ Indeed, courts have indicated that they give weight to fairness opinions in their analyses of fiduciary obhigation. For example, in Tanzer Economic Associates Profit Sharing Plan v. Universal Food Specialties, Inc., a New York court rehed on a fairness opinion obtained by the defendants, concluding that "[i]t is apparent that [the terms of the frecze-out constitute] no palpable or gross undervaluation, which on its face would shock the conscience of the Court."13 In Cottle v. Storer Communication, Inc. the Eleventh Circuit noted that "[t]he fact that the board consulted [an investinent bank] simply weighs in favor of finding that the directors did not abuse their discretion."14 And in Smith v. Van Gorkom, the court, in holding that the directors violated their duty of care, enphasized the directors' failure to obtain a fairness opinion. ${ }^{\text {is }}$

This Article analyzes the problems with judicial rehance on fairness opinions and considers the extent to which courts should give weight to such opinions. One aim of the Article is constructive-to suggest a judicial approach that may improve the rehability of fairness opinions; an-

"inadequate from a financial point of view"); Alleghany Corp. \& Investors Diversified Servs. Inc., Joint Proxy Statement annexes III, IV (Mar. 29, 1979) (merger is "fair from a financial standpoint" and "fair from a financial point of view," respectively); UOP Inc., Proxy Statement app. D (May 5, 1978) (merger is "fair and equitable").

10. See, eg., Lipton, Takeover Bids in the Target's Boardroom, 35 Bus. LAW. 101, 126 (1979) (banker provides detailed analysis and procedures used to develop fairness opinion); see also Gerstle v. Gamble-Skogmo, Inc., 298 F. Supp. 66, 83 (E.D.N.Y. 1969) (bank discloses financial data used in fairness opinion), modified, 478 F.2d 1281 (2d Cir. 1973); Unocal Corp. v. Mesa Petroleum Co., 493 A.2d 946, 950 (Del. 1985) (same). But see Hanson Trust PLC v. MI SCM Aequisition, Inc., 781 F.2d 264, 275-76 (2d Cir. 1986) (conclusory opinion; no documentary support provided).

11. See, e.g., Denison Mines Ltd. v. Fibreboard Corp., 388 F. Supp. 812, 821 (D. Del. 1974) (independence and reputation of investment banker adds persuasive support for management's position).

12. See Chazen, supra note 1, at 1442; Fischel, The Business Judgment Rule and the Trans Umion Case, 40 Bus. LAw. 1437, 1453 (1985); Note, Investment Bankers' Faimess Opinions in Corporate Control Transactions, 96 YAlE L.J. 119, 120-21 (1986).

13. 87 Misc. $2 d$ 167, 178, 383 N.Y.S.2d 472, 481 (Sup. Ct. 1976).

14. 849 F. $2 d$ 570, 578 (11th Cir. 1988).

15. 488 A.2d 858, 876-78 (Del. 1985); see also Treadway Cos. v. Care Corp., 638 F.2d 357, 384 (2d Cir. 1980) (faimess opinion evaluating merger proposal shows good faith); Kors v. Carey, 158 A.2d 136, 141 (Del. Ch. 1960) (use of outside experts factor in finding absence of misconduct); Alpert v. 28 Williams St. Corp., 63 N.Y.2d 557, 572, 473 N.E.2d 19, 27, 483 N.Y.S.2d 667, 676 (1984) (dictum) (fairness opinion good proof that freeze-out price fair); Danziger v. Kennecott Copper Corp., N.Y.L.J., Dec. 7, 1977, at 7, col. 1 (obtaining independent financial advice before making tender offer factor in holding that directors discharged fiduciary duties). 
other is critical-to show the limitations of possible improvements and, accordingly, to warn against excessive reliance on fairness opinions.

The first two parts of this Article systematically analyze the problems with fairness opinions. Part I shows that investment banks possess significant discretion in issuing fairness opinions. One source of this discretion hes in alternative definitions of "fair price." Another hes in the alternative ways of measuring fair price, however defined. As a result, investment banks have a choice among several widely disparate estimates of fair price, all of which are justifiable.

Part II examines the conflicts of imterest that investment banks face in issuing fairness opinions. Conflicts of interest derive from the investment banks' fee structure, from their desire to retain and attract clients, and possibly also from the bankers' psychological loyalty to managers. These conflicts encourage investment banks to render the opinions most conducive to the interests of the managers that hired them, and not those that best reflect the bankers' genuine beliefs. This part further argues that neither reputational concerns nor internal procedures and guidelines will significantly diminish this problem.

Part III suggests a judicial approach to fairness opinions. This approach describes how courts should scrutinize the definition of fairness, the measurement of fair price, and the banker-company relationship; the approach also suggests that courts should exercise substantial residual caution and limit their reliance on fairness opinions.

\section{The Problem of Discretion}

In this part, we show that investment banks possess substantial discretion in determining what prices are "fair" to sliareholders. Because of this discretion, investment banks can arrive at widely differing estimates of "fair price," all of which would be reasonable and none of which could be shown to be "wrong" (or unfair) under objective criteria. ${ }^{16}$ That financial analysts can regard widely differing figures as "fair" is problematic for two reasons. First, the subjective nature of fairness opimions reduces their value. Even if an investment bank rendered an opimion based on its genuine beliefs about fair price, that would be just one bank's opinion. Since other analysts could (legitimately) arrive at very different opinions, no single opinion should receive excessive weight. ${ }^{17}$

16. See, eg., Joseph v. Shell Oil Co., 482 A.2d 335, 339 (Del. Ch. 1984) (estimates ranging from S53 to $\mathbf{5 8 5}$ per share); Kahn v. United States Sugar Corp., No. 7313, slip op. at 18 (Del. Ch. Dec. 10, 1985) (Westlaw, 1985 WL 4449) (fron1 S52 to S122); Kaplan v. Goldsamt, 380 A.2d 556, 566-67 (Del. Ch. 1977) (from $\mathbf{5 7 . 2 5}$ to $\$ 9.50$ ).

17. A possible solution to this problem is to obtain more than one fairness opinion. See, eg., Brunswick Corp., Proxy Statement (Mar. 9, 1977) (charter amendment providing that certain trans- 
Second, and more importantly, this discretion enables investinent banks to act opportunistically. Investment bankers can formulate fairness opinions serving their and the managers' interests, rather than ones reflecting their best judgments of fair price. And, as the next part points out, investment banks have strong incentives to write opinions that satisfy the managers who hire them and negotiate their fees.

Investment banks' discretion in fashioning fairness opinions derives from two main sources. First, as section $A$ argues, the concept of fair price is ill-defined. Second, as section B shows, even financial analysts who use the same definition of fairness can differ in their assessments of fair price, because of the subjective nature of the estimation process.

\section{A. The Definitional Problem}

Underlying the differences in analysts' fair-price estimates is a conceptual confusion about the definition of fair price. ${ }^{18}$ Courts have failed to specify which definition of fair price investment banks should use, ${ }^{19}$ and investment banks generally do not disclose which definition of fair price they have used; ${ }^{20}$ their fairness opimions simply state that prices are "fair froin a financial point of view"21 or "inadequate."22 Different defimitions can, however, lead to significantly different estimates. ${ }^{23}$ Since a variety of justifiable definitions of fair price have been proposed, this definitional problem can be quite coinplex.

In addition, the suitability of any one definition depends on the kind

actions be found fair by two independent investınent banks). Even multiple faimess opinions, however, might not provide much information, because of the potentially wide discrepancies in price estimates. Furthermore, shareholders must bear the higher costs of multiple opinions.

18. Fair price is sometimes defined as the price at which a rational buyer with knowledge of the relevant facts would sell the shares in an arm's-length transaction. See Nathan \& Shapiro, Legal Standard of Faimess of Merger Terms Under Delaware Law, 2 DEL. J. CORP. L. 44, 48 (1977). This definition, however, begs the question: different rational buyers might consider different definitions of fair price appropriate.

19. See, eg., Kahn v. United States Sugar Corp., No. 7313, slip op. at 29 (Del. Ch. Dec. 10, 1985) (Westlaw, 1985 WL 4449) (court declined opportunity to specify appropriate definition of fair price); Joseph v. Shell Oil Co., 482 A.2d 335, 343-45 (Del. Ch. 1984) (same).

20. But cf. Kaplan, 380 A.2d at 563-64 (board compared faimess of price in negotiated share repurchase to cost of shares in tender offer).

21. See, eg., Crouse-Hinds Co. \& Belden Corp., supra note 9, exh. D. Even practitioners do not always know what "from a fnancial point of view" ineans. See Chazen, Friedman \& Feuerstein, Premiums and Liquidation Values: Their Effect on the Faimess of an Acquisition, in ElEVENTH ANinual institute on Securtties Regulation 143, 156 (A. Fleischer, M. Lipton \& R. Stevenson eds. 1980) (statement of Joseph Flom).

22. Cf. 1 M. Lipton \& E STEINBERGER, TAKeOVERS AND FREEZE-OUTS $\$ 6.01[1][c][i]$ (1988) (recommending that investment bank simply "opine as to the adequacy of the price offered").

23. See, eg., Joseph, 482 A.2d at 339 (different definitions resulted in estimates of $553,580-85$, and 591 per share); Kaplan, 380 A.2d at 556-67 (different definitions resulted in estimates ranging from $\$ 7.25$ to $\$ 8.25$ per share). 
of transaction at issue ${ }^{24}$ and the particular context of that transaction. ${ }^{25}$ Take, for example, a company facing an acquisition offer. The buyers might seek to acquire the company through a merger, a friendly tender offer, or a hostile tender offer. In this acquisition context, commentators have suggested a variety of definitions of fair price. First, fair price could refer to the value of the company as an independent entity-i.e., its value if it does not engage in the proposed acquisition or any other. ${ }^{26}$ One may seek to justify this definition of value as being most relevant to the choice facing the shareholders: should they approve the merger, tender the shares, and receive the value offered, or should they reject the merger and (at least for the moment) remain an independent entity?

Second, some have suggested that fair price should be defined as the value shareholders would receive if their company were auctioned off to the highest bidder. ${ }^{27}$ While shareholders do not necessarily have this choice, there is no reason in principle why a company should not be auctioned off if that would enable shareholders to obtain a higher price. Consequently, any price below the value that shareholders would receive in an auction is arguably "unfair" to the shareholders.

A third definition of fair price might be the value that bilateral, arm's-length bargaining would yield. ${ }^{28}$ This value is useful because it

24. See, eg., Chazen, supra note 1, at 1443-50 (proposing different faimess standards for nonnegotiated acquisitions by controlling shareholders, negotiated acquisitions by controlling shareholders, and acquisitions by unaffiliated purchasers). Making the definition of fair price dependent on the type of transaction in question poses the danger that banks will manipulate definitions to favor management. For example, an opinion that the terms of a merger are fair apparently means that the price is within a range of fair prices, but not the highest price attainable. See Chazen, Friedman \& Feuerstein, supra note 21, at 147. But an opinion that the terms of a hostile takeover bid are inadequate merely signifies that, even though the terms are fair, better terms can be obtained. See Weiss, The Law of Take Out Mergers: Weinberger v. UOP, Inc. Ushers in Phase Six, 4 CaRDozo L. REv. 245, 256 (1983).

25. Cf. Saffer, Touching All Bases in Setting Merger Prices, MERGers \& ACQuisitions, Fall 1984, at 42 (discussing which valuation method bidders should use in which context).

26. See, eg., Schwartz, The Faimess of Tender Offer Prices in Utilitarian Theory, $17 \mathrm{~J}$. LEGAL STUD. 165, 165-67 (1988). Because Schwartz believes that a company's independent value is given by the market price of its shares, he probably would see no need for fairness opinions written by bankers. If a company's shares are not publicly traded or if the share price does not reflect the company's value as an independent entity (e.g., because of the existence of significant nonpublic information), Schwartz would presumably advocate that a bank base its fairness opinion on the company's value as an independent entity.

27. See, eg., Bebchuk, The Case for Facilitating Competing Tender Offers, 95 Harv. L. REv. 1028, 1038-41 (1982); Gilson, A Structural Approach to Corporations: The Case Against Defensive Tactics in Tender Offers, 33 STAN. L. REV. 819, 868-75 (1981) (arguing for auction strategy in respouse to tender offer).

28. Cf. Pepper v. Litton, 308 U.S. 295, 306-07 (1939) (in self-dealing, test of faimess is whether transaction has earmarks of arm's-length bargain). This definition of fair price also follows froun the “sole owner standard" put fortiard in Bebchuk, The Sole Owner Standard for Takeover Policy, 17 J. LEGAL STCD. 197, 197-98 (1988). 
shows shareholders whether they might be better off not selling but rather returning to the bargaining table or waiting for another bid.29 This value also shows whether managers adequately represented shareholders in negotiating transaction terms and in structuring takeover defenses. In particular, use of this definition can indicate whether or not a conflict of interest affected managers during negotiation. ${ }^{30}$ Moreover, if an acquisition creates unique gains that would not arise from acquisition by another party, bargaining would arguably lead to a fair division of these gains.

This hist of definitions is not meant to be exhaustive; indeed, some may advance several other definitions of fair price, such as the value of the company's net assets ${ }^{31}$ or the value of the company as an independent entity plus a fraction of any gains resulting from the acquisition. Moreover, one can combine these definitions to forn new definitions: fair price, for example, can be defined as the average of several defimitions, under the argument that each definition captures one aspect of value. ${ }^{32}$

The appropriateness of any definition also might depend on the context of the acquisition in question. If several suitors showed interest in a company, an auction price might arguably be more appropriate than the independent value of the company; ${ }^{33}$ if the acquisition would produce

29. Empirical evidence shows that many unsuccessful merger negotiations and tender offers are followed by successful bids. Bradley, Desai \& $\mathrm{Kim}$, The Rationale Behind Interfirm Tender Offers, 11 J. FIN. ECON. 183, 188 (1983) (of 112 unsuccessful tender offer targets, 86 were acquired within 5 years). This suggests that shareholders can reasonably expect to realize a value above a company's independent value even if they reject an acquisition proposal.

30. Courts and commentators generally agree that corporate control transactions involve the potential for conflicts of interest. See R. Clark, Corporate LAw $\S \S 4.1,12.2 .5,13.2 .1$ (1986).

31. See, e.g., E.I. du Pont de Nemours \& Co. v. Collins, 432 U.S. 46, 54-56 (1977) (net asset value is fair price); Gerstle v. Gamble-Skogmo, Inc., 298 F. Supp. 66, 100 (E.D.N.Y. 1969) (same), modified, 478 F.2d 1281 (2d Cir. 1973).

32. If measurement of fair price according to each definition will result in an unbiased but inaccurate estimate of the true fair price, an appropriately weighted average will result in a more accurate estimate. See generally T. WONNACOTT \& R. WONNACOTT, INTROductory STATISTICS FOR BUSINESS AND ECONOMICS 129-31, 179-85 (2d ed. 1977) (Unless multiple estiunators are perfectly correlated, the variance of their sum is less than the sum of their variances; therefore, sonne weighted averages of several unbiased estimators will be a unore accurate estimator than any one estimator alone.).

Courts generally use a weighted average of different uneasures of value in the context of appraisal rights. See, e.g., Piemonte v. New Boston Garden Corp., 377 Mass. 719, 733, 387 N.E.2d 1145,1153 (1979) (upholding weighted average of market value, earnings value, and net asset value); Endicott Johnson Corp. v. Bade, 37 N.Y.2d 585, 587, 338 N.E.2d 614, 616, 376 N.Y.S.2d 103, 106 (1975) (to determine fair value, court should consider net asset value, investment value, and market value). But $c f$. Weinberger v. UOP, Inc., 457 A.2d 701, 712 (Del. 1983) (overruling precedents that used weighted average to exclusion of other accepted valuation techniques).

33. See Revlon, Inc. v. MacAndrews \& Forbes Holdings, Inc., 506 A.2d 173, 182 (Del. 1986) (when company's sale to one of several bidders becounes inevitable, directors obliged to conduct neutral auction). 
unique gains, the negotiation price might arguably be more appropriate than the auction price. Another factor that investment banks apparently consider relevant is whether a bank renders a fairness opinion in a friendly or a hostile deal. In the former, the opinion indicates whether a reasonably prudent board could accept the offered terms; ${ }^{34}$ in the latter, it states whether the bank believes that a better offer can be obtained. ${ }^{35}$

Turning from acquisitions to other transactions, it seems that every type of transaction inight require a different definition of fair price. Take freeze-out mergers as an example. In these mergers, fair price might focus on the coinpany's value as an independent entity, ${ }^{36}$ as the market price of the minority shares, ${ }^{37}$ or as the price the minority sliares would receive if auctioned off as a block. ${ }^{38}$ In addition, one might add to any of these ineasures a fraction of any freeze-out gains ${ }^{39}$ that inight arise, or an appropriation for the tax expenses and reinvestment transaction costs ${ }^{40}$ that minority shareholders must incur. ${ }^{41}$

34. As investment bankers like to stress, a "fair" price is not the highest price obtainable, but rather a price within the range that a reasonable and prudent board would accept. See Chazen, Friedman \& Feverstein, supra note 21, at 147; Fleischer, A "Faimess Letter" is Just an Opinion, N.Y. Times, June 8, 1986, §3, at 2, col. 3.

35. See Weiss, supra note 24, at 256.

36. See DEL CODE ANN. tit. 8, §262(h) (1983) (in determining fair value for purposes of appraisal rights, cont should ignore any value arising from accomplishment or expectation of merger and consolidation); MODEL BUS. CORP. ACT \$ 13.01(3) (1985) (defining "fair value" for purposes of discenters' rights as excluding any "appreciation or depreciation in anticipation of the corporate action unless exclusion would be inequitable").

37. See Easterbrook \& Fischel, Corporate Control Transactions, 91 YALE L.J. 698, 723-31 (1982) (minority shareholders should receive market value for shares in freeze-out merger); $c f$. DEL. CODE ANN. tit. 8, $\$ 262(b)(1)$ (appraisal remedy not available in cases involving publicly traded stock).

38. See Chazen, Friedman \& Feuerstein, supra note 21, at 160 (price obtainable for minority shares as block provides possible measure of fair price). These authors believe that the block price would be below the market price, since investors would have to sell at a liquidity discount. If the same person owned all the minority shares, however, he would have greater incentives and abilities to momitor the majority sharelolders. In such a case, the majority would presumably be less able to divert gains from the minority, and the minority stock's block price might exceed the value of the stock to dispersed imvestors.

39. See Brudney \& Chirelstein, Fair Shares in Corporate Mergers and Takeovers, "88 HaRv. L. REv. 297, 345 (1974) (fair treatment requires that gains be shared).

40. Toms, Compensating Shareholders Frozen Out in Two-Step Mergers, 78 Colum. L. REv. 548,577 \& n.104 (1978) (suggesting modification of traditional imtrinsic value standard to compensate for factors reducing actual value of frozen-out shareholder interests).

41. In other transactions, different definitions of fair price can be justified. For example, in a management buyout, fair price might mean: a company's independent value; the market price of the shares; the price obtainable in an auction; the independent value plus a fraction of the gains expected from the buyout (e.g., tax savings from increased leverage and gains from unproved incentives to managers); or the value of the company assuming management made all clianges it planned to make after the buyout (which would include tax savings from increased leverage but might not include gains from improved incentives to managers). Cf. Lowenstem, Management Buyouts, 85 Colti. L. REV. 730, 779-84 (1985) (arguing for an auction rule in leveraged buyouts). 
Investment bankers are free to choose from any of these definitions. ${ }^{42}$ In part III we will suggest a twofold approach to help solve the definitional problem: first, courts should clarify which definitions of fair price they view as legitimate; second, investunent banks should state the definitions underlying their opimions. As explained below, however, the definitional problem is not the only source of bankers' discretion. Even in the absence of this definitional problem, investment banks would still retain significant discretion because of the ineasurement problem.

\section{B. The Measurement Problem}

Even financial analyses that employ the same definition of fair price can arrive at widely differing results. ${ }^{43}$ To ineasure fair price, however defined, any analysis must make a variety of simplifications, assumptions, and estimates. Since analysts simplify, assume, and estimate in different ways $^{44}$ that are all reasonable and justifiable, they often arrive at different estimates of fair price.45

Assume, for example, that the appropriate definition of fair price is a company's independent value. An analyst inust first decide whether he should estimate this value by the value of the company's net assets, ${ }^{46}$ the discounted value of the company's future profits, ${ }^{47}$ a multiple of past earnings, ${ }^{48}$ the discounted value of future dividend payments, ${ }^{49}$ the share

42. Managers sometimes select the definition of faimess that investment banks unust use in writing opinions. See, eg., Kaplan v. Goldsamt, 380 A.2d 556, 563 (Del. Ch. 1977) (in negotiated share repurchase, bank asked to estimate cost of buying equivalent amount of shares through tender offer); Longstreth, New Controls for Leveraged Buyouts, N.Y. Times, Nov. 6, 1983, § 3, at 3, col. 2 (bankers sometimes asked not to consider liquidation value).

43. Some courts have recognized the subjective nature of price estimates. See Radol v. Thomas, 534 F. Supp. 1302, 1305 (S.D. Ohio 1982) (price estimates necessarily imprecise); Kaplan, 380 A.2d at 567 (valuation depends upon numerous subjective judgments); $c f$. Kahn v. United States Sugar Corp., No. 7313, slip op. at 18 (Del. Ch. Dec. 10, 1985) (Westlaw, 1985 WL 4449) (expert valuations based on subjective judgments); Joseph v. Shell Oil Co., 482 A.2d 335, 341 (Del. Ch. 1984) (expert appraisers usually express different opimions even if using same data).

44. For examples of how different assumptions can influence estimates, see Kahn, No. 7313, slip op. at 18; Kaplan, 380 A.2d at 567 (estimates depend on approach taken by those rendering them).

45. See also Fischel, supra note 12, at 1452 (discounted-cash-flow technique can "come up with just about anything"); $c f$. Note, supra note 12, at 124 (modern valuation techniques do not permit investnuent bankers to determine fair price with absolute precision).

46. See, eg., Piemonte v. New Boston Garden Corp., 377 Mass. 719, 733, 387 N.E.2d 1145, 1153 (1979) (net asset value factor in determining fair value); Endicott Johnson Corp. v. Bade, 37 N.Y.2d 585, 587, 338 N.E.2d 614, 616, 376 N.Y.S.2d 103, 106 (1975) (same).

47. See, e.g., B. MAlkiel, A RaNiom Walk Down Wall STreet 115 (4th ed. 1985) (describing fundamental analysis); see also Weinberger v. UOP, Inc., 457 A.2d 701, 712 (Del. 1983).

48. See, e,g., Kahn, No. 7313, slip op. at 19 (experts used inultiples of past earnings to determine value); In re Valuation of Common Stock of Libby, McNeill \& Libby, 406 A.2d 54, 65.66 (Me. 1979) (multiple of past earnings given reight of $40 \%$ in calculating fair value under appraisal statute). 
price, ${ }^{50}$ or some average of these measures. ${ }^{51}$

Suppose the analyst decides to estimate the company's value by the discounted value of its future profits. She must then collect information on which to base his estimates. At this stage, the analyst determines the appropriate information sources, the required amount of information, the accuracy of any company-supplied information, and the necessity of imdependently verifying that information.

Based on this information, the analyst must make assumptions about increases in company costs, revenues, ${ }^{52}$ and future tax rates..$^{53}$ These assumptions, in turn, depend on such unpredictable variables as future inflation rates, new product development, market competition, and the general political climate. Moreover, the analyst might have to repeat her calculations for each of a company's product lines.

Finally, the analyst must estimate the discount rate for future profits. Assume that the analyst decides to use the capital asset pricing model to determine the disçount rate. Even if she wanted to apply the same discount rate in each time period and to each item of revenue and cost, she would have to determine the risk-free rate, calculate the covariance of cash flows with the company's market portfolio, and estimate the market risk premium. ${ }^{54}$

Assume that the impossible happens and two analysts agree that a company will have profits of $\$ 100,000$ in each coming year, but one analyst determines that the proper discount rate is eight percent a year while the other believes the proper rate is ten percent a year. This two percent difference in the discount rates will result in estimates that diverge by twenty-five percent. The first analyst will estimate the company's value at $\$ 1,250,000$, while the second analyst will estimate it at $\$ 1,000,000.55$ Of course, if the analysts do not agree on the amount of future profits,

49. R. Brealy \& S. Myers, Principles of Corporate Finance 45 (2d ed. 1984).

50. See, eg., Easterbrook \& Fischel, Auctions and Sunk Costs in Tender Offers, 35 Stan. L. REv. 1, 13-14 \& n.28 (1982) (liquid markets offer ready price for shares); Easterbrook \& Fischel, The Proper Role of a Target's Maregement in Responding to a Tender Offer, 94 HaRv. L. REv. $1161,1165-67$ (1981) (under efficient capital market theory, share price represents true value of firm); Schwartz, supre note 26, at 165; cf. DEL. CODE ANR. tit. 8, § 262(b)(1) (1983) (appraisal rights not available for publicly traded stocks).

51. See, eg. Piemonte v. New Boston Garden Corp., 377 Mass. 719, 733, 387 N.E.2d 1145, 1153 (1979) (weighted average); Endicott Johnson Corp. v. Bade, 37 N.Y.2d 585, 587, 338 N.E.2d 614, 616, 376 N.Y.S.2d 103, 106 (1975).

52. See, eg. R. Brealy \& S. MYERS, supra note 49, at 85.96.

53. See, eg., Herskowitz v. Nutri/System, Inc., 857 F.2d 179, 184 (3rd Cir. 1988) (fairness opinion assumed tax laws would not change), cert denied, 109 S. Ct. 1315 (1989).

54. R. BREALY \& S. MYERS, supra note 49, at 128-35 (describing how to apply the capital asset pricing model).

55. One can obtain the present value of such a cash flow by dividing the annual flot by the difference between the discount rate and the absolute rate of growth of the cash flor:. 
their estimates might be even further apart. ${ }^{56}$ For example, if the first analyst thinks profits will grow at an annual rate of four percent, and the second analyst thinks they will grow at only two percent, their respective estimates will be $\$ 2,500,000$ and $\$ 1,250,000$. These analyses-both legitimate under prevailing standards-would produce very different conclusions about whether a price of, say, $\$ 2,000,000$ is fair.

A different definition of fair price conld complicate the estimation process even more. Assume, for example, that fair price is defined as the result of takeover negotiations conducted bilaterally and at arm's length, which presumably includes part of the net gains from an acquisition. Assume that an analyst hired by the acquiring corporation first estimates the value of the acquiring company as an independent entity. Next, he estimates the value of the target company as an independent entity and the value of both companies together. From these three figures, the analyst then calculates the net gains from the transaction.

Estimating the value of the target company and of both companies together creates even greater leeway than estimating just the value of the acquiring company. The analyst will ordinarily lave less informationand will thus be forced to make more estimates-about the target company than about the company that hired him. Similarly, the analyst will often not know how the surviving company will be managed, and even if he did, determining the effects on value wonld leave a wide margin of tolerance.

Fimally, in deciding how to split the net gains from the acquisition, the analyst can justify the-use of several estimation metlods. The analyst might assess how companies in other transactions liave split gains; alternatively, he might assume that gains would be divided equally, on a per. dollar basis, ${ }^{57}$ on a percentage of independent value basis, ${ }^{58}$ or on some other basis.

In sum, however fair price is defined, an investment bank might base its estimate on a variety of justifiable information sources, assumptions, and measurement techniques. ${ }^{59}$ By relying on different sources of infor-

56. Statistically independent estimates of each item would limit differences between analysts' estimates as a whole. The estimates on each item would tend to balance the estimate as a whole: an analyst who makes a relatively high estimate of the profits on product $A$ might make a relatively low estimate of the profits on prodnct $B$.

There are, however, two reasons to believe that estimates on each item are not independent. First, some analysts might take a generally positive or negative approach to the developinents in the company's industry or the economy in general. Second, as part III will show, analysts have incentives to arrive at price estimates that satisfy the managers that hired them.

57. See Brudney \& Chirelstein, supro note 39 , at 316.

58. See id at 320-21.

59. Even if an analyst regards the stock price as the fair price, he must decide whether to include or ignore several factors: a prospective transaction's impact, the timing of disclosure for that 
mation, making different assumptions, and using different techniques, banks might arrive at widely different results. Even if no definitional problem existed, investment banks would retain significant discretion.

\section{The Problem of Conflicts of Interest}

The existence of substantial discretion would present significant problems to those wishing to rely on fairness opinions even if bankers faced no conflict of interest. Even if all bankers sought to render opimions best reflectimg their judgment, the presence of discretion would imply that any one opinion might only reflect one banker's opinion and, as such, differ markedly from opimons that other analysts would reach. As this part explains, however, the existence of discretion presents an especially severe problem because bankers do face significant conflicts of interest. Bankers are thus likely to use their discretion to render opinions that serve the interests of managers. By managers, we refer to those officers and directors of corporations who wield the power to select investment bankers and set their compensation schemes. ${ }^{60}$ For example, if managers want shareholders to approve a merger, banks will tend to conclude that the merger terms are fair. On the other hand, if managers want to adopt defenses to a hostile takeover, banks will tend to conclude that the proposed takeover terms are unfair.

This Part demonstrates the pervasiveness of such conflicts of interest by analyzing their sources and by refutimg the alleged grounds for the independence of investment bankers. The Part first considers in detail the causes of conflicts of interest: the fee structure for compensating investment banks and the incentives that structure creates, the banks' desire to retain and attract chents, and psychological and social factors. Lastly, this Part argues that investment banks' reputational concerns and internal procedures will not eliminate these conflicts of interest.

$\therefore$

transaction, and the effect of this information on the stock price. Cf. Fischel, The Appraisal Remedy in Corporate Law, 1983 AM. B. Found. RES. J. 875, 893-94 (describing econometric market model for reconstructing market price while excluding effects of a prospective corporate control transaction).

60. Many have expressed the view that faimess opinions often do nothing more than rubberstamp management decisions. See, eg.. McGough, Faimess for Hire, Forbes, July 29, 1985, at 52; Weiss, supra note 24, at 255; Note, supra note 12, at 127-28; Stein, Investment Banking's Dirty Little Secret, N.Y. Tinies, June 8, 1986, § 3, at 2, col. 3; Longstreth, supra note 42, at 3, cols, 3-4; see also Fischel, supre note 14, at 1453 (some experts always willing to opine that price significantly higher than share price is fair). Thus, the contribution of this part lies not in the novelty of its claim that a conflict-of-mterest problem exists but rather in its systematic analysis of the factors producing this problem. 


\section{A. The Fee Structure}

One reason why investinent banks have an incentive to write fairness opinions consistent with managerial desires stems from the fee structure under which banks are compensated. An investment bank generally does inore than just write the fairness opinion for a transaction; the same bank often controls other financial aspects of the transaction. ${ }^{61}$ For example, in a merger, a bank writing a fairness opinion inight also give a company general financial advice; 62 in a hostile takeover defense, the bank might arrange financial aspects of a lock-up option ${ }^{63}$ or a poison pill. 64

Although banks often receive a fixed fee for fairness opinions, ${ }^{65}$ other fees that investment banks receive are frequently contingent. ${ }^{66}$ For example, in many friendly deals, a significant fraction of the total fee is payable on the condition that the transaction is consummated, ${ }^{67}$ and the size of this contingent fee may depend on the company's sale price. ${ }^{68}$ In other instanees, fees are contingent on a raider's failure in a proxy chal-

61. See Chazen, supra note 1, at 1442-43 (typically, faimess opinion is only one of several services furnished by investment bank); see also Dynamics Corp. of Am. v. CTS Corp., 794 F.2d 250, 257 (7th Cir. 1986) (investment bank provided fairness opinion and advice on proxy fight), rev'd. 481 U.S. 69 (1987); MacAndrews \& Forbes Holdings v. Revion, Inc., 501 A.2d 1239, 1243-44 (Del. Ch. 1985) (investment bank wrote faimess opinion and structured bostile tender defense), aff'd, 506 A.2d 173 (Del. 1986).

62. See, eg., Kohn v. American Metal Climax, Inc., 458 F.2d 255, 267 (3d Cir. 1972) (bank served as general financial adviser during amalgamation discussions), cert denied, 409 U.S. 874 (1972); Gerstle v. Gamble-Skogmo, Inc., 298 F. Supp. 66, $82-83$ (E.D.N.Y. 1969) (bank provided services involving debt issue prior to merger), modified, 478 F.2d 1281 (2d Cir. 1973); Alleghany Corp. \& Investors Diversified Serv. Inc, supra note 9, at 21 (Alleghany's investment bank to receive fees for financial advice and fairness opinion).

63. See, eg., Hanson Trust PLC v. ML SCM Acquisition, Inc., 781 F.2d 264, 270-71 (2d Cir. 1986) (Goldman Sachs structured lock-up option and declared that it was fair).

64. See eg., Dynamics Corp., 794 F.2d at 257.58 (Smith Barney structured poison pill and wrote opinion that tender offer was unfair).

65. See, eg., Weinberger v. UOP, Inc., 457 A.2d 701, 706 (Del. 1983) (Lehman Brothers received $\$ 150,000$ for fairness opimion).

66. Investment banks usually receive a single fee for all services involving one transaction. Confidential interview with Shearson Lehman Hutton personnel (Nov. 1988).

67. For example, in the acquisition of ABC by Capital Cities, ABC's bank was to receive $\$ 2$ million if ABC's shareholders approved the deal and $\mathbf{5 4 . 5}$ million if the deal was finalized. American Broadcasting Companies, Inc. \& Capital Cities Communications, Inc., Joint Proxy Statement 7 (May 10, 1985).

68. See, e.g., Radol v. Thomas, 534 F. Supp. 1302, 1315 n.19 (S.D. Ohio 1982) (investment bank received base fee plus 1\% of share price in excess of 585); Joseph v. Shell Oil Co., 482 A.2d 335, 339 (Det. Ch. 1984) (mvestment bank received fixed sum plus a bonus dependent on price eventually paid for minority shares). See generally Carrington, Merger Advisers Say the Big Fees They're Charging Are Warranted, Wall St. J., July 17, 1981, at 29, col. 3, col. 4 (in friendly deals, seller's investment bank usually receives percentage fee). 
lenge, ${ }^{69}$ on the bank's recruitment of a white knight, ${ }^{70}$ or on the company's making the fairness opinion public. ${ }^{71}$

Fees contingent on a transaction's consummation create enormous incentives for investment bankers to help execute deals. ${ }^{72}$ In such situations, investment banks face two alternatives: they can earn contingent fees if they characterize management proposals as fair, or they can garner modest fees if deals collapse as a result of their opinions. ${ }^{73}$

For instance, in the merger of Cleveland Electric and Toledo Edison, Morgan Stanley was to receive $\$ 3.794$ million if the companies actually merged, but only $\$ 350,000$ otherwise. ${ }^{74}$ In the acquisition of Allied Stores by Campeau, Goldman Sachs was to receive a straight fee of $\$ 1$ million and an additional fee in the amount of one-third of one percent (estimated to be $\$ 13$ million) of the total price paid for Allied shares, minus the $\$ 1$ million straight fee..$^{75}$

Another example is the involvement of Smith Barney in Dynamics' hostile tender offer and proxy contest for CTS. CTS retained the bank to write a fairness opinion on the tender offer and to give other financial advice. ${ }^{76}$ If Dynamics, the lostile raider, lost the proxy contest, Smith Barney would receive a bonus of $\$ 75,000.77$ Thus, Sinith Barney had an incentive to find the tender offer unfair. If Smith Barney had found the tender offer fair, Dynamics would have been more likely to win the contest and the bank would have lost its bonus. Similarly, if a bank's fees are contingent on the appearance of a white knight, the bank has incentives to find the original raider's offer unfair; if fees are contingent on the opin-

69. See, eg., Dynamies Corp. of Am. v. CTS Corp., 794 F.2d 250, 257 (7th Cir. 1986) (in hostile tender offer, investment bank hired to determine faimess received bonus if hostile suitor lost proxy fight), rep'd, 481 U.S. 69 (1987).

70. See, eg. Radol, 534 F. Supp. at 1315 (bank's fee contingent upon success of white knight's tender offer).

71. See, eg., Herskowitz v. Nutri/System, Inc., 857 F.2d 179, 183 (3d Cir. 1988) (bank received S75,000 if opinion published and \$50,000 if not), cert denied, 109 S. C. 1315 (1989); Anderson v. Boothe, 103 F.R.D. 430, 435 (D. Minn. 1984) (bank received fixed fee of \$250,000 for opinion and additional $\$ 150,000$ if opinion tiade publicly available).

72. See Anderson, 103 F.R.D. at 436 (contingent fees could bias fairness opinion); Note, supra note 12 , at 128 (contingent fees create conflict of interest).

73. To be sure, an investment bank's judgment that a price is unfair does not necessarily destroy a deal; nor does an opinion that the proposed terms are fair ensure a transaction's consummation. As long as a favorable opinion increases the chances of a deal's consummation, though, investment banks will face the incentives we describe.

74. Centerior Energy Corp., Cleveland Elec. Illum'n Co. \& Toledo Edison Co., Joint Proxy Statement 12 (Oct. 4, 1985).

75. Allied Stores Corp., Information Statement 9 (Dec. 9, 1986).

76. Dynamies Corp. of Am. v. CIS Corp., 794 F.2d 250, 257 (7th Cir. 1986), rev'd, 481 U.S. 69 (1987).

77. Id. 
ion's publication, a bank will have an incentive to render an opinion favorable to inanagement interests.

Since banks are coinpensated primarily for services other than writing fairness opinions, they have incentives to render pro-management opinions even in situations involving noncontingent fees, because such opinions will typically generate inore work than opposition opinions. ${ }^{78}$ For example, a merger-killing negative opinion will destroy all the business that a inerger would have created for a bank. Thus, even under a noncontingent fee scheine, banks' pro-management opimions create liigher revenues (and profits). The difference in incentives between contingent and noncontimgent fees is therefore ouly a matter of degree: investinent banks compensated on the basis of work performed will face smaller (but still positive) ineentives to generate pro-inanagement opinions than will banks compensated on a contingent basis. ${ }^{79}$

Soine investment bankers and commentators argue that contingent fees operate in a different way: under a compensation sclieme that makes fees a percentage of the final deal price, banks maximize fees by seeking high prices. ${ }^{80}$ Thus, the scheme provides banks with incentives to find deals unfair in order to induce higher sales prices. However, only contingent fees that depend on final sales prices ("percentage fees") provide such countervailing incentives to a seller's imvestment bank, and fees are often contingent on other factors. ${ }^{81}$ For example, they can be contingent on a deal's execution but not be derived froin the price payable to shareholders. ${ }^{82}$ Such contingent fces create no countervailing incentives, and purchase prices under such a scheme are not likely to increase.

78. Management might desire an opinion that a particular merger proposal or tender offer is unfair in order to justify defensive tactics. In some cases, the fees that banks can earn in the prevented corporate control transactions might be larger than the fees from structuring the defenses. Even in such cases, though, investment banks will have an incentive to render the opinion desired by management. If the bank were to issue an opinion favoring the transaction, management would in all likelihood not retain the writing bank for the control transaction, and the bank would not profit from larger fees. If the bank writes the opinion desired by management, it will at least earn the small fees for structuring the defenses.

79. Incentives to write pro-management opinions under a contingent fee system will be larger than those generated under a noncontingent fee system ouly if an investment bank has worked on a deal prior to writing the fairness opinion at issue. In such a case, the faimess opinion will affect both the expected profits from any work to be done in the future and the coinpensation for work already completed. If, however, the bank has rendered no other serviees before writing the faimess opinion, incentives under both compensation systems should be equal. Under either systen, the faimess opinion will affect expected profits from work to be done in the future, and there is no reason to assume that these expected profits are larger if the bank is coinpensated on a contingency basis.

80. See, e.g., Fleischer, supra note 34, at 2, col. 4 (contingent fees act as incentive for investment banks to obtain highest possible price).

81. See supra notes $75-77$ and accompanying text.

82. See, e.g., Beatrice Cos., Proxy Statement 12 (Mar. 11, 1986) (fec of $\$ 15$ million payable inimediately when merger consummated; otherwise payable in installments). 
Moreover, even with respect to percentage fees, a bank that rejects a proposed price as unfair must consider the possibility that such a rejection will jeopardize the entire deal. ${ }^{83}$ An attempt to push up the price will pay only if the likelihood of killing the deal is relatively small. Assume, for example, that an investment bank stands to receive $0.1 \%$ of the purchase price on consummation of a deal. A bank wonld benefit from trying to raise the price from $\$ 100$ million to $\$ 110$ million only if the probability of killing the deal were less than approximately $10 \%$. Thus, even with percentage fees, banks often would not attempt to increase purchase prices.

In summary, both contingent and noncontimgent fee structures create incentives for investment banks to write opinions aligned with management interests. Under contingent fee structures, pro-inanagement opinions increase the likelihood that the specified contingencies will take place; under noncontingent fee schemes, such opinions increase the amount of work available to the writing bank. In both cases, pro-manageinent opinions increase imvestment banks' revenues.

\section{B. The Desire to Attract and Retain Clients}

Assume, as before, that an investment bank receives $0.1 \%$ of the purchase price if a potential sale is consummated. Assunne further that the bank perceives only a $5 \%$ chance that increasing the price from $\$ 100$ million to $\$ 110$ million will kill the transaction. A bank attempting to maximize its fees should try to increase the purchase price, because the expected fee froin the sale wonld increase from $\$ 100,000$ to $\$ 104,500$.

In each transaction, however, an mvestment bank must consider both the possible fees froin this particnlar transaction and the impact of that transaction on future business. Investment banks have an incentive to write opinions that attract future chents. The ultiniate question, then, remains: what do clients want from investunent banks when they retain them to write fairness opinions? Investment banks that deliver what clients want will attract future business; mvestinent banks that do not, will not.

Although formally an investment bank's clients are corporations themselves, it is certain officers and directors-referred to liere as inanagers-who select investment banks. Since managers decide which investment banks to hire, banks will attract business by satisfying managers. Because managers are likely to be well informed about an investinent

83. Note that fees of investment banks representing buyers are sometimes a percentage of the sales price See, eg., Carrington, supra note 68, at 29, col. 4 (First Boston, representing du Pont in its bid for Conoco, received $0.2 \%$ of sales price as fee). Apparently, in these instances, buyers do not believe that such fces create strong incentives for investment banks to increase sales prices. 
bank's reputation and its approach to fairness opinions, the bank's performance affects its future employment prospects with both its present client and other potential clients. In particular, one would imagine that word would quickly spread if an investment bank killed a deal by trying to increase the purchase price of a corporation. Furthermore, major law firms retained by managers provide information about the reputation of most investment banks. Thus, incentives created by investment banks' desire to be hired for future transactions are potentially much stronger than incentives created by fee structures in an imdividual transaction.

Because investment banks lave strong mcentives to satisfy managers, fairness opinions are unlikely to serve as an effective independent check on managerial activity. To the contrary, the desire to retain and attract clients will lead investment banks to write the fairness opinions that inanagers wish to see. Banks that adapt their fairness opinions to the wishes of managers will tend to be rehired, whereas banks that write contrary opinions are less likely to be retained.

\section{Psychological and Social Factors}

The psychological and social loyalty that investment bankers sometimes fecl toward managers reinforces the economic incentives created by the fee structure and by the desire to retain and attract clients. Because many investment bankers personally know the managers who hired them, ${ }^{84}$ bankers tend to feel more sympathetic to managers than to shareholders and tend to place greater weight on managerial goals and views. As a result, fairness opinions often favor managerial interests. ${ }^{85}$

Even in the absence of persoual relations between bankers and managers, though, many transactions create an atmosphere of common purpose that tends to reduce bankers' objectivity. ${ }^{86}$ For instance, a bank evaluating a transaction may have assisted managers in creating and structuring that transaction. ${ }^{87} \mathrm{Or}$, a bank retained to defend against a hostile takeover might help to search for a white knight. ${ }^{88}$ In such in-

84. See, eg., Weinberger v. UOP, Inc., 457 A.2d 701, 706 (Del. 1983) (fairness opinion prepared by investment banker who was also a longtime director of UOP).

85. Cf. Gerstle v. Gamble-Skogmo, Inc., 298 F. Supp. 66, 95 (E.D.N.Y. 1969) (prior business relation raises doubts about investment bank's impartiality), modified, $478 \mathrm{~F} .2 \mathrm{~d} 1281$ (2d Cir. 1973).

86. See, eg., MacAndrews \& Forbes Holdings v. Revlon, Inc., 501 A.2d 1239, 1243 (Del. Ch. 1985) (investment bank and management together developed defensive share repurchase plan and poison pill), aff'd, 506 A.2d 173 (Del. 1986).

87. See, eg., Gerstle, 298 F. Supp. at 95 (structuring merger and evaluating its fairness "blurred" investment bank's "lenses," resulting in failure to note erroneous property valuation).

88. See, eg., Hanson Trust PLC v. ML SCM Acquisition, Inc., 781 F.2d 264, 268-69, 271 (2d Cir. 1986) (investment banker involved both in preparation of fairness opinion and in search for white knight). 
stances, bankers and managers share a team spirit, ${ }^{89}$ even a siege mentality. In addition, banks and corporations often establish continuing relationships that add to this collaborative atınosplere. 90 These relationships may lead bankers to give undue weight to managers' goals, at the cost of shareholder interests.

\section{Objections to the Analysis}

This section discusses and rejects the commonly given reasons why bankers are likely to write fairness opinions that reflect their best, unbiased judgments. In particular, the section argues: first, that a concern for professional reputation does not lead investinent banks to render unbiased fairness opinions, and second, that internal procedures and guidelines fail to eliminate the conflicts of interest facing investinent banks.

1. Professional Reputation. One familiar argument lolds that investment banks' desire to maintain a professional reputation may lead them to provide unbiased fairness opinions. A professional reputation for quality work is an important asset to an investinent bank, so the argument goes, and banks might well be reluctant to jeopardize such a reputation by writing biased opinions. Managers use these opinions to convince courts that fiduciary duties have been met and to persuade shareholders to approve transactions.91 Since courts and shareholders would place less weight on fairness opmions known to be biased, banks have a clear interest im upholding their reputation for unbiased opinions.

Courts, however, have not indicated that they pay close attention to the trustworthiness of fairness opinions written by specific banks.92 Rather, courts fail to differentiate anong investment banks as long as

89. See, eg, Macdndrews \& Forbes, 501 A.2d at 1243 (investment bankers, managers, and lawyers together developed program to protect company against tender offer).

90. For example, Merrill Lynch represented Alleghany in its merger with Investors Diversified Services (IDS) in 1979. Prior to that, Merrill Lynch had represented Alleghany in its 1975 merger with MLS; in a 1977 tender offer for IDS stock; twice in 1977 with respect to IDS Realty Trust; and again in 1978 with respect to the trust. In total, Merrill Lynch earned revenues of over $\$ 500,000$ in these transactions. Similarly, in the three years prior to the Alleghany merger, Saloinon Brothers, which represented IDS, had earned about $\$ 4.5$ million from earher representation of IDS. Alleghany Corp. \& Investors Diversified Servs. Inc., supra note 9, at 27-28.

91. See supra notes 11-15 and accompanying text.

92. In the acquisition of Stokely-Van Camp, Dillon Read, an investment bank, advised the directors that the proposed price of $\$ 55$ in a management buyout was fair. Quaker Oats eventually acquired Stokely for $\$ 77$ per share and Quaker Oats apparently made significant profits in the deal. McGough, supra note 60 , at 52 . Nonetheless, courts have not discounted faimess opinions issued by Dillon Read. See, e.g., Cottle v. Storer Communication, Inc., 849 F.2d 570, 578 (11th Cir. 1988) (fairness opinion by Dillon Read given weight). 
those banks have sufficient credentials. ${ }^{93}$ Furthermore, to the extent that courts do pay attention to professional reputation, they are likely to evaluate fairness opinions on the basis of a bank's general reputation rather than on the basis of its reputation with respect to fairness opinions. ${ }^{94}$ Shareholders, while they might pay more attention to the general reputation of investment banks, are likely to have less specific information about investment banks than managers have. Shareholders are, at most, aware of the general reputation of investment banks, 95 and this knowledge alone should not preclude unanagers from selecting an investment bank that is willing to write a pro-management opinion. ${ }^{96}$ Thus, investment banks that enjoy a broad reputation for providing high-quality work will still have incentives to write pro-management fairness opinions.

To maintain credibility with courts and shareholders, investment banks need ouly avoid writing fairness opinions that they cannot reasonably justify. That is, investment banks must not opine that utterly unreasonable prices are fair or that clearly fair prices are inadequate. If a particular bank's opimions were repeatedly outside this range of legitinuate fair prices, its reputation would decline so noticeably that courts and shareholders would give less weight to its opinions. As part I points out, however, such a reasonableness requirement iniposes only a himited constraint on choices available to imvestment banks; banks may still write pro-naanagement opinions as long as their opinions renain within this range of legitinate fair prices.

2. Internal Procedures and Guidelines. One might also argue that internal procedures and guidelines ensure that investment banks write unbiased opinions. A bank will issue fairness opinions only according to these procedures and guidelines. For example, some investment

93. Cf. Kahn v. United States Sugar Corp., No. 7313, slip op. at 29 (Del. Ch. Dec. 10, 1985) (Westlaw, 1985 WL 4449) (noting "inpressive credentials" of experts that valued same company at $\$ 52$ and $\$ 122$ per share, respectively).

94. See, e.g., Denison Mines Itd. v. Fibreboard Corp., 388 F. Supp. 812, 821 (D. Del. 1974) (noting reputation of Lehman Brothers in investment banking field).

95. Cf. id. (finding it difficult to overestimate impact to sharelolders of reference to Lehunan Brothers).

96. One inight wonder why courts and shareholders do not pay closer attention to the reputation of investment banks. One reason why courts do not scrutinize reputation might be that legally admissible evidence will not provide a reliable picture of reputation. Another possible reason is that all reputable investment banks give pro-management fairness opinions. Thus, a court could not denounce a particular bank's behavior as different from the norm; all that courts could possibly do is to criticize the behavior of the whole investment banking industry. Shareholders, of course, lack the incentives to acquire information about the reputation of investment banks, because inost of them own only a small fraction of a company's shares and because their vote is unlikely to make a difference. 
banks have established internal committees that monitor the issuance of fairness opinions. ${ }^{97}$

A primary reason for establishing these procedures or guidelines, however, is to ensure that individual bankers act in the interest of the investment bank as a whole. ${ }^{98}$ If it is in the interest of the bank itself to write pro-nranagenient opinions, procedures and guidelines will direct employees to do the same. Internal procedures and guidelines thns should tend to produce fairness opinions that increase fees and help to retain and attract chients. 99

To be sure, guidelines and procedures have some beneficial effect on the quality of fairness opinions. In order to niaintain a professional reputation, banks are likely to write guidelines and procedures ensuring that all fairness opinions have a reasonable basis. ${ }^{100}$ Furthermore, internal procedures and guidelines might try to limit the psychological and social factors which lead individual bankers to issue an opinion that is nore pro-nianagement than is in the bank's interest. However, the incentives to render pro-management opinions that are created by the fee structure and the desire to retain and attract clients affect the interest of the bank itself, rather than ouly the interests of individual bankers. Therefore, internal procedures and guidelines should be expected to solidify, rather than reduce, the force of these pro-management incentives.

97. Shearson Lehman Hutton has a committee that momitors all faimess opinions before they are issued. Confidential interview, supra note 66.

98. Another reason, presumably, is to avoid legal liability arising from faimess opinions. In that case, the procedures and guidelines can be expected to reach as far as potential legal liability. But to establish liability shareholders must establish that the imvestment banker knowingly misrepresented the contents of a faimess opinion. See Note, supra note 12, at 128-30 (reviewing the standards for investment banker liability under both federal and state law). Even under a uegligence rule, investment bankers would not be liable for a faimess opinion that could be reasonably justified.

99. The various formulations ued in faimess opinions inight illustrate how guidelines can produce pro-management opinions. In mergers, fairness opinions conventionally state whether the terms are fair, i.e., within a range of values a reasonable prudent board would accept. In hostile tender offers, fairness opinions state whether the terms are adequate, i.e, whether better terms could be obtained. See Weiss, supra note 24 , at 256 . Since terms must generally be higher to be adequate than to be fair, terms that are fair in mergers (which the managers generally like to approve) are inadequate in hostile tender offers (which the managers generally do not like to approve). The lack of specific guidelines can also serve these purposes. Shearson Lehman Hutton, for example, has no written guidelines and no fixed standards for issuing fairness opinious. Rather, each case is evaluated individnally. Confidential interview, supra note 66 . Such an ad hoc approach would enable a bank, if it so desired, to conform the content of the faimess opinion to the wishes of the management.

100. For instance, Shearson Lehman Hutton considers varions measures of fairness before it issues a faimess opinion. Confidential interview, supra note 66. 


\section{A RECOMMENDED JUdiCIAL APPROACH}

This part suggests a judicial approach for dealing with the problems analyzed above. By following this approach, courts can reduce both the discretion that investment banks currently possess and the conflicts of interest that they face. Sections A, B, and C explain, respectively, how courts should scrutinize the definition of fairness, the measurement of fair price, and the banker-company relationship. Finally, Section D suggests that, even with such scrutiny, courts should still exercise substantial residual caution in dealing with fairness opinions.

\section{A. Scrutinizing the Definition of Fair Price}

The two most natural ways to attack the multiple-definition problem are: first, for courts to clarify the definitions of fairness that banks should use while preparing opinions, and second, for banks to disclose the definition underlying each opinion. Courts should recognize the conceptual confusion that surrounds the definition of fairness and try to build a system of definitions through precedent. These precedents will, over time, establish definitions appropriate to each context. Although these precedents alone may not eliminate all uncertainty about the proper definition of fairness, it is likely to reduce the range of definitions that are arguably proper in any one transaction.

In particular, courts should examine the different standards that imvestment banks use to evaluate friendly deals and hostile deals. In friendly transactions, banks couch opinions in terms of fairness (Would a rational board accept the offer?), whereas in hostile deals banks evaluate offers in terms of adequacy (Can a higher offer be obtained?). ${ }^{101}$ Unless courts conclude that these different standards are warranted, they should not give weight to fairness opinions written in this fashion. ${ }^{102}$

At the same time, courts should require that investment banks exphicitly state the definitions of fairness used in preparing their opinions. Banks should be free to use several definitions if they so desire; in that case, however, banks should state under which definitions the price is fair, and under which definitions the price is unfair. For example, an opinion should not state that a price is fair from a financial point of view; rather, it should state that the price is fair compared to the pre-mergerannouncement stock price or fair compared to the price the company

101. See Weiss, supra note 24, at 256.

102. See id. (in take-out mergers, fairness opinions should be framed in terms of adequacy, not faimess). 
would carry in an auction. ${ }^{103}$

The inclusion of explicit definitions of fairness will assist judicial analysis of fairness opinions. The respect accorded any given fairness opinion should depend on whether the definitions used in the opinion's preparation conform to the appropriate contextual definitions. Thus, if courts liave establislıed a proper definition, investment banks will know exactly how to prepare opinions that the courts will respect. But even if such a definition is not judicially established when a fairness opinion is written, courts will be able to judge the extent to which the definition used deviates froin the proper definition and then decide how inuch weight to give the fairness opinion.

This approach is not overly deinanding. It neither requires that fairness opinions use the judicially established definitions nor requires that companies obtain fairness opinions. If, however, a company does obtain a fairness opinion, the opinion should explicitly state the definitions it uses. And, as courts determine which definitions are proper, they should indicate them to enable companies to obtain opinions based on those defimitions, and courts should give weight only to opinions that use such definitions.

\section{B. Scrutinizing the Measurement of Fair Price}

The problein of evaluating bankers' measurement processes is more difficult to solve. Price estimates are inherently iniprecise. Courts are unable (and slould not atteinpt) to specify in advance what assumptions bankers should make and what valuation techniques they should use. ${ }^{104}$ Rather, courts should weigh an opinion depending on whetler it states a range of fair prices ${ }^{105}$ and on the extent to which its conclusion is sensitive to its assumptions. Thereby, fairness opinions will convey inore imformation and investment banks will have less discretion.

103. One might wonder why investment bankers have not themselves clarified the definitions of fair price. One reason why the confusion has remained might be, as we suggested in part II, that managers benefit from it: the less defined the concept of fair price, the higher the discretion to the investment bankers, and the greater their opportunity to arrive at a satisfactory opinion.

104. Cf. Weinberger v. UOP, Inc., 457 A.2d 701, 713 (Del. 1983) (all generally accepted valuation techniques may be used to estimate fair value for purposes of appraisal rights). Note that the standard for faimess opinions should be based on valuation techniques used in estimating prices for purposes other than faimess opinions. If the standards were based on techniques used solely for faimess opinions, the investment banking industry would tend to develop standards that would make it easy to render pro-manageinent opinions.

105. Investment banks are often reluctant to specify numbers for fair prices. Chazen, Friednan \& Feuerstein, supra note 21, at 146 . However, in sone cases, they are apparently willing to give ranges of fair prices. See, eg., Kahn v. United States Sugar Corp., No. 7313, shp op. at 30 (Del. Ch. Dec. 10, 1985) (Westlaw, 1985 WL 4449) (Bear Stearns gives price range of $\$ 62$ to $\$ 68$ per share). 
In concluding that a price is fair without giving a range of prices, banks can base opinions on barely reasonable assumptions. For example, if reasonable fair stock prices for a company involved in a inerger range from $\$ 50$ to $\$ 90$ per share, a bank will have no difficulty in justifying an opinion that a inerger price of $\$ 55$ is fair. If banks are forced to give a range of fair prices, however, it will becoine harder for them to make bad deals look good. Because assumptions become more difficult to justify as they becoine more extreine, banks will be unable to come up with arbitrary price ranges. For instance, a bank might arrive at $\$ 50$ to $\$ 70$ as a fair price range, with the inerger price of $\$ 55$ close to the bottom of this range. With a lower price range, however (say, $\$ 45$ to $\$ 65$ ), the bank might open itself to attack with respect to the (fairly unreasonable) assumptions that resulted in a $\$ 45$ estimate. In such an example, directors would incur the risk of censure for accepting a blatantly biased fairness opinion, and banks would incur the risk of gaining a reputation for rendering unreasonable opinions.

Analyzing the sensitivity of price estimates to assumptions serves the same purpose as requiring specification of fair-price ranges. In performing sensitivity analyses, analysts construct a base scenario and then show how the outcome of that scenario varies with changes in assumptions. ${ }^{106}$ In showing how estimates change as assumptions vary, this analysis indicates the type of assumptions one must make for a seemingly fair price to become unfair. A sensitivity analysis, like specification of price ranges, will tend to show how fair or unfair a price is, not merely whether the price is fair or not.

In giving weight to fairness opinions, courts should consider whether a corporation's directors have been told a range of fair prices and the results of a sensitivity analysis. Take a hostile tender offer as an example: if directors approve a defensive measure, a fairness opinion should receive greater weight if the directors were informed that the hostile bid was significantly below the range of fair prices and would remain below such a range even if certain (specified) assuinptions were inodified, and less weight if directors were merely told that the price was inadequate, was in the middle of the range of fair prices, or was unfair under some "reasonable" assumptions but fair under other "reasonable" assumptions.

Finally, in certam sufficiently unusual situations, courts should be willing even to engage in an independent review of the reasonableness of the assumptions and techniques ${ }^{107}$ used to prepare fairness opinions and,

106. See generally R. BREALY \& S. MYERS, supra note 49, at 195-202.

107. See, e.g. Kahn, No. 7313 , slip op. at $29-33$ (court examined assumptions on which valuations were based). 
in turn, the reasonableness of directors' reliance on those opinions. ${ }^{108}$ Such scrutiny, of course, requires that banks disclose their assumptions and techniques to directors and to courts. ${ }^{109}$

However, even if all these steps are taken, investunent banks will retain a significant amount of discretion. Bankers can reasonably differ on the upper and lower limits of fair price ranges and on methods of performing sensitivity analyses. And courts must allow directors to rely on a variety of reasonable assumptions and techniques. Thus, our approach will only constrain - but not eliminate-investunent banks' ability to manipulate fair-price measurements.

\section{Scrutinizing the Banker-Company Relationship}

As discussed, ${ }^{110}$ the nature of the relatiouship between investment banks and corporations creates conflicts of interest that tend to produce a pro-inanagement bias in fairness opinions. Courts should reduce this bias by scrutinizing the banker-corporation relationship. As a first step, courts should discount fairness opinions for which any part of the bank's fee is contingent. Fees contingent on results other than the eventual purchase price are especially suspect because they give banks no countervailing incentives to increase the purchase price. Although some courts have realized that investinent banks in such situations hardly function as independent and objective advisors, ${ }^{111}$ most courts have not expressed such concerns about contingent fee arrangements. ${ }^{112}$

One might respond that contingent fees create efficiencies that make their use desirable. In particular, contingent fees may give investment banks performance incentives. For example, fees contingent on the price shareholders receive for their shares will give banks an incentive to increase the purchase price. Fees that are contingent on winning a proxy contest or on procuring a white knight will provide incentives to assist in the proxy contest or to look for a white knight.

108. See, eg, Hanson Trust PLC v. ML SCM Acquisition, Inc., 781 F.2d 264, 275 (2d Cir. 1986) (directors obligated to become reasonably familiar with investment banker's report); see also Note, supra note 12, at 134 (directors slould be able to rely only on faimess opinions that conform to accepted standards in investment banking industry).

109. Proxy statements do not generally include calculations made in arriving at their faimess opinion. Cf. Chazen, Friedman \& Feuerstein, supra note 21, at 151 (calculations usually not helpful).

110. See supra notes $60-99$ and accompanying text.

111. See Dynamics Corp. of Am. v. CTS Corp., 794 F.2d 250, 257 (7th Cir. 1986) (Posner, J.) (critical comment on incentives creaied by contingent fee), rev'd, 481 U.S. 69 (1987).

112. Many opinions fail to mention that the investment bank involved received a contingent fee. See, eg. Cottle v. Storer Communication, Inc., 849 F.2d 570, 578 (11th Cir. 1988). 
We do not suggest, however, that investment banks should be prohibited from negotiating and executing any type of fee arrangennent, including contingent fees. ${ }^{113}$ Rather, we only point out that courts must recognize the imevitable conflicts of interest that contingent fees create and should accordingly discount fairness opinions written under contingent fee arrangements.

Note that the beneficial incentives created by contingent fees do not relate to fairness opinions themselves; rather, the incentives operate with respect to other serviees provided by investment banks. If managers want both unbiased fairness opinions and contingent fee arrangements, they can hire a second investment bank solely to write a fairness opinion. By doing so, they maintain incentives for the bank in charge of the bulk of a transaction without creating a conflict of interest for the bank writing the fairness opinion. Managers, though, remain free to obtain fairness opinions from banks compensated under contingent fees (opinions to which courts will give less weight) or, for that matter, to obtain no fairness opinions whatsoever.

Hiring a second investment bank-preferably one that is not $\mathrm{m}$ volved in other aspects of the transaction and has no longstanding relationship with the corporation-is preferable to eliminating the contingent fee for other reasons as well. As we have shown, even noncontingent fees create incentives to render pro-management fairness opinions; these pro-management opinions usually help to create followup work for the writing bank. If, however, a bank writing a fairness opinion is not involved with other aspects of the transaction, such a bank will not be influenced by the possibility that a particular fairness opinion might create more work. Furthermore, hiring an "outside" bank will reduce the psychological and social factors that tend to create pro-inanagement fairness opinions. A second investment bank will be at a distance from the transaction and thus more likely to write a more neutral opinion.

Retaining a second investment bank just to write a fairness opinion will of course create some costs. This second bank will have to duplicate some of the lead bank's work. Lacking familiarity with the company, an "outside" bank will need to do inore work to determine fair prices than would an investment bank that already knows the company. A second bank might also be hard to find. By writing a fairness opinion for a fairly small fee, such a bank disqualifies itself from representing other potential

113. One might draw an analogy, though, to the position of public accountants, which is similas to that of imvestment bankers. Managers hire accountants in order to certify books prepared under management supervision. Accountants, however, may not be compensated by contingent fees. Code of Professiosial Ethics § 302, Rule 302.01 (Am. Inst. of Certified Pub. Accountants 1988). 
bidders for the company and earning a significantly larger fee. Lastly, although the second investment bank earns only a relatively small fee, it stands to bear all the possible liability. ${ }^{114}$

One should not, however, exaggerate the extent of these costs. The cost of issuing a fairness opinion is often trivial in relation to the amounts involved in a transaction as a whole. ${ }^{115}$ The concern about disqualification would seem to apply only in the context of hostile takeovers; a bank asked to evaluate the fairness of a merger or a freeze-out price would have little hope of being hired by a newly emerging bidder. Furthermore, market forces can respond to concerns about disqualification; if these concerns really matter, some specialized investment banks that do nothing but write fairness opinions (and thus do not have to worry about disqualification) will emerge. Lastly, investment banks can insure against legal liability and, in any case, the threat of legal hability will have positive effects as investment banks exercise more care and neutrality in rendering fairness opinions. ${ }^{116}$

\section{Residual Skepticism}

Even if courts follow the above approach, we feel that they should still use substantial caution in relying on fairness opinions. While our approach addresses some of the problems inherent in fairness opinions, significant residual probleins remain. First, although our approach does much to reduce the discretion rooted in the definition of fairness, imvestment banks would retain significant discretion in measuring fair price. Estimating the value of uncertain future income streams, assets that are not openly traded in the market, or prices that companies would command in an auction that is never held is an inherently subjective and iniprecise activity. Specifying price ranges and performing sensitivity analyses would reduce these subjective elements, but even these remedies would not magieally transform fairness opinions into objective yardsticks of a company's value.

Second, our approach does not completely eliminate all incentives for banks to write pro-management fairness opinions. The scrutiny we propose would reduce the conflicts of interest inherent in the fee structure, but would not reduce the incentives created by the desire to retain and attract chients. Even uninvolved "outside" banks would still have

114. See Note, supra note 12, at 135-39 (discussing investment banker's potential liability).

115. See, e.g., Weinberger v. UOP, Inc., 457 A.2d 701, 704-06 (Del. 1983) (bank given \$150,000 for faimess opinion in cash tender offer of over $\$ 90,000,000$, which involved a premium over market price of more than $\$ 30,000,000$ ).

116. Cf. Tote, supra note 12 , at 135 (advocating increased liability of investment banks). 
incentives to deliver opinions that retain and attract clients. ${ }^{117}$

Third, even if these reputational incentives to render pro-management opinions were absent, the siniple fact that managers select investment banks leads to biased opinions. Investment banking firms are likely to differ in low they measure fair prices and in whether their estiniates tend to coine out high or low. For example, it inight become known that a particular bank tends to rely on adjusted share prices to determine fair prices. Managers could select that bank if such a method of determining price were likely to result in the desired fairness opinion.

Fourth, courts would have to remam aware that fairness opinions are, in part, necessarily based on information provided by nanagers themselves, such as managerial opinions about future business prospects ${ }^{118}$ or internal profit forecasts. ${ }^{119}$ Managers have an obvious incentive to provide banks with the kind of information that tends to encourage pro-management opinions. ${ }^{120}$ Investnent banks generally do not verify the information they receive in preparing their opinions; ${ }^{121}$ rather, they premise their opinions on the assumption that the information given to them is accurate and complete. ${ }^{122}$ For this reason as well, fairness opinions will tend to remam pro-management in character.

In light of these residual problems, the question arises whether courts slould siniply ignore fairness opinions. We think not: for all their problems, fairness opinions have a positive potential. Although investment banks retain some discretion, many prices will clearly fall inside or outside specified reasonable price ranges and banks will thus have to find those prices fair or unfair: Even though investment banks will have incentives to develop pro-management reputations, if they are too blatant about it, they will risk losing credibility with the courts. Therefore, as

117. Such incentives would be especially strong for investment banks that specialize in writing faimess opinions. Those banks would derive a significant part of their revenues fron these opinions. A reputation for not agreeing with managers would go to the heart of their business.

118. See, eg., Crouse-Hinds Co. \& Belden Corp., supra note 9, exhs. C, D (both investment banks, in preparing their fairness opinions, held discussions with management about future business prospects).

119. See, e.g., Alleghany Corp. \& Investors Diversified Servs. Inc., supra note 9, annex III (Merrill Lynch using internal forecasts in developing its faimess opinion).

120. One commentator has proposed that directors should be under a duty to convey accurate information to investment banks. See Note, supro note 12, at 132-33. Such a rule unight prevent outright lies, but not more subtle forms of bias.

121. See, eg., Crouse-Hinds Co. \& Belden Corp., supra note 9, exhs. C, D: Alleghany Corp. \& Investors Diversified Servs. Inc., supra note 9, annexes III, IV (no independent verification of information provided by the company); see also Denison Mines Lid. v. Fibreboard Corp., 388 F. Supp. 812,822 (D. Del. 1974) (investment bank relied on management valuation of tiniber assets and conducted no independent evaluation).

122. See, eg., Crouse-Hinds Co. \& Belden Corp., supra note 9. exhs. C, D: Alleghany Corp. \& Investors Diversified Servs. Inc.. supra note 9. annexes III, IV. 
long as excessive judicial reliance on fairness opinions is avoided, such opinions do have the potential for serving a useful function.

\section{CONCLUSION}

The purpose of this Article has been to analyze the problems with fairness opinions and to suggest a judicial approach for evaluating such opinions. Fairness opinions are problematic because investment banks have substantial discretion in rendering such opinions. The banks' discretion derives from two sources: first, the concept of fair value is not clearly defined, and banks can thus choose among several proposed defimitions of fairness; second, the subjective nature of the estimation process creates discretion in ineasuring fair price, however it is defined.

Investment banks face conflicts of interest that lead them to use their discretion to render pro-management fairness opinions. For one, pro-management opinions generally increase banks' revenue. Such opinions make banks more likely to receive contingent fces or, where a bank does not receive a contingent fee, generate further work. Furtherinore, rendering pro-management opinions will help banks to retain and attract chents. These incentives are enhanced by psychological and social loyalty that some bankẹrs may feel towards managers. Neither the desire to preserve a professional reputation nor the presence of internal procedures will significantly reduce these problems.

To deal with these problems, we recommend an approach that helps courts to serutinize definitions of fair price, the measurement of fair price, and the company-banker relationship. First, courts should develop a definition of fair price that they consider proper. Investment banks, in turn, should disclose their definitions of fair price. Second, to reduce discretion in the measurement of fair price, the weight given to a fairness opinion should depend on whether the opinion contains infornation on the range of fair prices and on the sensitivity of the price estimate. Third, courts should discount fairness opinions when the writing bank is compensated by a contingent fee, when it is involved in other aspects of the transaction, and when it has had prior dealings with the company at issue. This discounting will reduce incentives for rendering pro-management opinions. In any case, since the recommended approach would reduce, but not eliminate, discretion and pro-management incentives, courts should exercise substantial caution in assessing and giving weight to fairness opinions. 